\title{
THE DARK SIDE OF INTERVENTIONS AND PEACE SUPPORT OPERATIONS: THE SOMALIA CASE
}

DOI: $10.20542 / 2307-1494-2021-2-189-191$

Malito D. V. Destabilising Interventions in Somalia: Sovereignty Transformations and Subversions. Abington: Routledge, 2020. $154 \mathrm{p}$.

The book by Debora Malito analyses the over 30 years long conflict in Somalia, focusing on the effect that interventions by international actors had in that country. The author's main focus is on destabilising effects that these interventions, undertaken as peace operations or as unilateral interventions by neighbours of Somalia, had on Somalia and its political and institutional sphere.

The author's main methodological point of departure is to consider the relationship existing between interveners and intervened, and how these actions influenced the stability of the country. Malito is quite sceptical about indexes that cover some issues difficult to measure, such as the Failed State Index. While the study is hardly a resume of the entire conflict and concentrates on effects of interventions by other countries/institution for the target region, the point that when intra-state conflicts become internationalized, they also become more difficult to settle and lead to proliferation of actors competing with each other, is the book's crosscutting theme.

In the first part of the book, the author focuses on the issue of sovereignty and offers a critique of the institutionalist and Weberian way of state building that, according to her, has blatantly failed in the Somali case. An interpretation of "sovereignty" as a static concept does not consider the dynamism of creation and dissolution of polities and the fact that even sovereignty in its classic, European form needed a lot of instability and violence to come out of chaos. This is why, for the author, aiming to stabilize Somalia through a fixed and state-centric European approach was itself a problem. Moreover, the Westphalian way of thinking would define the situation in Somalia during several past decades as a chaos, due to its multitude of non-state actors. However, some of these actors have tried to provide stability to sub-national territories, despite the destabilized state of the country at large. The author blames external actors for their focus on tackling non-state actors only - she argues that, as a matter of fact, the interveners are usually blind to destabilization brought by international interventions that often bring more damage than local factors such as clan-based society or the proliferation of social norms and institution that are not in line with the internationally accepted ones.

In chapter 2, the author rises the problem of the arbitrary nature of state borders, especially in Africa, that were drawn in the context of the monolithic Westphalian order and helped create unstable states with grievances between populations. More recently, this has been exacerbated by neo-colonial dependency of former colonies on their colonizers, leaving to the international community the right to protect "weak states" from disaster. However, this dependency often prevents any attempts or ways for a state in question to self-stabilize, but instead prolongs instability or even adds more destabilization.

In chapter 3, the author explores the commonly accepted relationship between being a "failed state" and the occurrence of armed conflict and the emergence of terrorist movements. However, this "orthodoxy", as she calls it, is seen more as an excuse used by the international community to intervene: no wonder that this narrative has been very influential during the 
Global War on Terror. The chapter reflects the hypocrisy behind international interventions, including the idea that states are all on the same ground, but some have less power to defend their sovereignty: for the authors this gives to the external actors a convenient pretext to intervene for re-establishing stability. The author also stresses the fact that although the interveners usually proclaim themselves to be impartial, they actually tend to support some local factions over others, which is particularly true for Somalia.

These chapters constitute the first part of the book. Thus, the author gives a long premise before going in depth to the Somali case, focusing on the ambiguity of interventions and the problems faced by post-colonial countries.

In the remaining four chapters, Malito concentrates on the conflict in Somalia. After describing the steps that brought to the outbreak of the conflict that erupted since Siad Barre's removal from power in 1991, the author analyses the first decade of foreign interventions in Somalia. The object of her study is the U.S.-UN-led administration of peace missions (UNISOM I and II and UNITAF): she shows how the interveners manifestly supported one of the two factions, resulting from the split of the main group that brought down the former president Barre, the United Somali Congress. The interveners chose Ali Mahdi, a weaker actor, instead of Mohamed Farrah Aidid, but still wanted to negotiate with both factions, radicalizing the conflict between the two and creating the anti-UN narrative. The author also looks into the parallel process of state-building in Somaliland that seemed to be effective and was sustained by a compromise between democratic institutions and clan society. Malito uses the case of Somaliland (as a de facto state that reached certain stability by separating from increasingly conflict-torn and chaotic Somalia) to criticize the notion of immutability of sovereignty.

Chapter 5 is probably the most interesting from the point of armed conflict analysis. It concentrates on the effects of the Ethiopia-Eritrea conflict on the neighbouring Somalia. The author focuses on how these two countries used Somalia as an instrument to pressure one another. Eritrea that aimed at destabilizing the southern border of Ethiopia funded Somali separatists of the Oromo region, but also Islamist groups. Ethiopia then had to intervene militarily to the central regions of Somalia to tackle Somali insurgents that retreated to their mother-state to reorganize the insurgency. The author also disaggregates the clash between Ethiopia and Eritrea into the military and the diplomatic confrontations. Ethiopia, as the regional hegemon in the Horn of Africa, played a larger role in the peace talks and had more influence on the peacekeeping missions, mostly after the retrenchment of the U.S. forces in the mid-1990s. Eritrea, in turn, often proposed solutions that were opposite to the ones suggested by Ethiopia (i. e., a unitary state for Somalia), but were close to the ones supported by the Arab states. From this chapter it is possible to see how instability can be spurred and exacerbated by rivalries between neighbouring countries, proving Somalia to be a proxy war in all senses.

Chapter 6 concentrates on the rise of the Global War on Terror in the 2000s and on the effect it had on Somalia. The author stresses the role of Ethiopia that, along with the United States, was the main actor in the new wave of interventions undertaken under Operation Enduring Freedom. Ethiopia is blamed for using the intervention in Somalia that should have targeted terrorists and pirates only, to pursue its own interests and to tackle the factions opposed to Ethiopia and its policies even if they were not involved in either terrorism, or piracy. This ambiguity stimulated further polarization across the country, making it increasingly difficult to settle the situation through peace talks that have always been unsuccessful and full of mistrust and suspicious between the parties. The author stresses the radicalization that such interventions bring to the targeted countries. For example, the factions considered as enemies of the coalition led by Ethiopia were funded by Eritrea just to counterbalance Ethiopia's actions and presence. Moreover, some of these factions (notably the Islamist movement "al-Shabab") radicalized and started to use terrorist tactics in increasingly asymmetrical confrontation, 
marked by superiority of the interveners, in another consequence of the growing internationalization of the conflict.

Chapter 7 summarizes and synthesizes conceptual points elaborated by the author through the book. The main points of the book is her critique of the Weberian concept of sovereignty and the role of interventions by external actors who intervene to "restore" this sovereignty for "weak" or "failed" states. In addition, she explores in detail destabilizing implications of internationalization of armed conflicts against her background critique of the international order.

The book's main hallmark is its unique focus on the effects that an international intervention, be it a unilateral one or a multilateral "peace mission", has on a "host" country. The example of Somalia is exemplary and useful to understand other similar cases: the author often compares the Somali scenario with the situation in other countries that have experienced similar conflicts (such as Iraq and Afghanistan where the effects of interventions by external actors, including in internal conflicts, have contributed to prolonging the conflict, multiplied the number of actors involved and complicated the actual or potential peace processes.

The first part of the book is probably excessively theoretical and methodological, explaining in depth theories of sovereignty, state development and dependence in the international system. This results in less space devoted to detailed analysis of the conflict in Somalia than there could have been: so, a reader may first need to get some background of the conflict, with its multitude of actors and various interests at stake. The main purpose of the book is to offer a critique of the Westphalian concept of sovereignty and the flaws that it produces in international interventions to, and for, contemporary states in conflict. Hence the book is more theoretical than focused on armed conflict analysis.

Another criticism that could be addressed to the author is that the bulk of the responsibility to the enduring Somali conflict is attributed to external actors. There is, however, little research in the book on internal causes related to the specifics and the evolution of the Somali society and local actors.

While only limited attention is paid to radicalization of armed, mostly Islamist, groups, it fits well into the author's focus on destabilization in the context of contemporary internationalized civil wars. The part related to the Eritrea-Ethiopia proxy war is also useful to understand external conflicts that can still have major effect on the "host state", as shown by heavy interference of both countries in Somalia.

Overall, the book should be particularly useful for those readers who are interested in the dependence theory in international affairs or are concerned about how global and regional powers make use of their interventions in conflict-torn countries. However, if one wants to find a detailed analysis of this protracted armed conflict, a clear description of the local actors, the rivalries among them, and how some of them choose to radicalize, the book by Debora Malito will probably not suffice. Still, it remains a sound point of departure for those who look for an explanation of military interventions and peace operations in Somalia from a more critical point of view.

Giuseppe Romano (Italy) Libera Università Internazionale degli Studi Sociali Guido Carli (LUISS), Rome

ORCID: 0000-0001-8651-8641 